\title{
ANALISIS SENTIMEN BAHASA INDONESIA PADA TWITTER MENGGUNAKAN STRUKTUR TREE BERBASIS LEKSIKON
}

\author{
Feby Tri Saputra*1, Yani Nurhadryani ${ }^{2}$, Sony Hartono Wijaya ${ }^{3}$, Defina ${ }^{4}$ \\ ${ }^{1,2,3}$ Departemen Ilmu Komputer, Fakultas Matematika dan Ilmu Pengetahuan Alam, Institut Pertanian Bogor \\ ${ }^{4}$ Departemen Ilmu Keluarga dan Konsumen Fakultas Ekologi Manusia, Institut Pertanian Bogor \\ Email: ${ }^{1}$ saputra_feby@apps.ipb.ac.id, 2yani_nurhadryani@ apps.ipb.ac.id, ${ }^{3}$ sony @ apps.ipb.ac.id, \\ defina@apps.ipb.ac.id
}

(Naskah masuk: 21 September 2020, diterima untuk diterbitkan: 02 Februari 2021)

\begin{abstract}
Abstrak
Jumlah opini di media sosial seperti Twitter tersebar luas sehingga tidak mungkin membaca semua opini untuk mendapatkan seluruh sentimen. Analisis sentimen merupakan salah satu metode untuk mengatasi masalah tersebut. Salah satu pendekatan dalam analisis sentimen adalah berbasis leksikon. Pendekatan berbasis leksikon dapat menghasilkan performa yang baik pada lintas topik pembicaraan tanpa memerlukan pelatihan data. Namun, pendekatan berbasis leksikon sangat bergantung pada kelengkapan dan keragaman sentimen leksikon. Selain itu, hubungan antarkata sangat penting untuk diperhatikan karena dapat mengubah polaritas sentimen pada teks. Hubungan antarkata dapat direpresentasikan dengan baik menggunakan struktur tree. Penelitian ini menggunakan struktur tree sebagai interpretasi hubungan antarkata dalam pembentukan kalimat dengan menambahan kata ke dalam sentimen leksikon. Metode berbasis tree diujikan pada data dengan lintas topik seperti data twit Pilgub Jabar 2018, Pilpres 2019, dan pandemik COVID-19. Ketiga data uji memiliki proporsi kelas yang tidak seimbang, dengan kelas terbanyak merupakan kelas positif. Metode berbasis tree menghasilkan akurasi sebesar 64,97\% (meningkat 1,26\%) pada data Pilgub Jabar 2018, 64,33\% (meningkat 11,41\%) pada data Pilpres 2019, dan 66,24\% (meningkat 7,61\%) pada data pandemik COVID-19. Metode berbasis tree dapat menghasilkan akurasi yang stabil pada beberapa lintas topik dibuktikan dengan standar deviasi akurasi yang kecil $(0,97 \%)$ bahkan lebih kecil dari metode tanpa tree $(5,4 \%)$. Metode berbasis tree dapat meningkatkan weighted fl-measure pada data Pilpres 2019 sebesar 10,45\% dan data pandemik COVID-19 sebesar 8,1\%, sedangkan hasil pada data Pilgub 2018 tidak berbeda secara signifikan. Hasil akurasi dan weighted fl-measure memiliki selisih yang kecil sehingga pengukuran akurasi valid dan tidak bias terhadap data tidak seimbang.
\end{abstract}

Kata kunci: analisis sentimen, hubungan antarkata, lexicon-based, struktur tree, twitter

\section{INDONESIA SENTIMENT ANALYSIS ON TWITTER USING A LEXICON-BASED TREE CONSTRUCTION}

\begin{abstract}
The number of opinions on social media like Twitter is so widespread that it's impossible to read all those opinions to get all the sentiments. Sentiment analysis is one of the methods that could overcome this problem. The lexiconbased approach is one of the sentiment analysis approaches which perform well across data topics without training. However, the lexicon-based approach relies heavily on the completeness and diversity of sentiment lexicons. The relationship between words is important because it could change the sentiment polarity in the text. The tree structure could represent the relationship between words well. This study uses a tree structure as an interpretation of the relationship between words in a sentence. The tree structure is constructed by adding words to the lexicon sentiment. The tree-based method is tested on cross-topic data such as the tweet data of the 2018 West Java Governor Election, the 2019 Presidential Election, and the COVID-19 pandemic. All data used has an unbalanced class proportion, with the positive class being dominant. The accuracy results of the tree-based method on all data consecutively are $64.97 \%$ (increased by $1.26 \%$ ), $64.33 \%$ (increased by $11.41 \%$ ), and $66.24 \%$ (increased by $7.61 \%$ ). The tree-based method produce stable accuracy on several topics proved by the small accuracies standard deviation (0.97\%) that even smaller than the non-tree method (5.4\%). The weighted f1-measure increases of the tree-based method on all data consecutively are $0 \%$ (equal), $10.45 \%$, and $8.1 \%$. The small difference between the weighted fl-measure and accuracy concludes that the accuracy resulted is valid.
\end{abstract}

Keywords: lexicon-based, sentiment analysis, tree structure, twitter, words relationship 


\section{PENDAHULUAN}

Jumlah opini publik yang tersebar di berbagai media semakin meningkat seiring berkembangnya teknologi, informasi, dan komunikasi. Melihat hal tersebut, tidak mungkin untuk membaca setiap opini yang disampaikan satu per satu untuk mendapatkan sentimen yang disampaikan oleh masyarakat. Analisis sentimen atau biasa disebut opinion mining dapat dijadikan suatu solusi untuk mendapatkan sentimen publik.

Pada era digital seperti sekarang ini, media sosial telah menjadi salah satu wadah yang sering digunakan masyarakat dalam mengutarakan opininya. Data pada tahun 2018 menunjukkan bahwa pengguna internet Indonesia telah mencapai $64,79 \%$ dari total penduduk Indonesia yang berjumlah 264,16 juta jiwa. Adapun jumlah pengguna internet Indonesia adalah 171,17 juta jiwa. Adapun layanan media sosial termasuk ke dalam layanan nomor dua yang sering diakses dengan persentase pengguna sebesar 18,9\% (APJII, 2018). Salah satu media sosial yang berpotensi menyebarkan informasi secara cepat dan meluas adalah Twitter (Kwak dkk., 2010). Hal ini didukung oleh hasil survei We are social pada bulan Januari 2020 yang menunjukkan bahwa Twitter menduduki peringkat ke5 pengguna terbanyak di Indonesia setelah YouTube, WhatsApp, Facebook, dan Instagram (Simon, 2020).

Analisis sentimen dapat mengklasifikasikan teks yang mengandung opini sebagai kelas positif, negatif, atau netral secara otomatis (Indurkhya dan Damerau, 2010). Secara umum, pendekatan dalam analisis sentimen terbagi ke dalam dua hal, yaitu pendekatan berbasis corpus dan pendekatan berbasis leksikon. Pendekatan berbasis corpus memiliki akurasi yang lebih tinggi dibandingkan dengan pendekatan berbasis leksikon (Abdulla dkk., 2013). Namun, pendekatan berbasis corpus sangat bergantung pada kualitas dan jumlah data pelatihan (Pamungkas dan Putri, 2016). Akurasi pada pendekatan berbasis leksikon dapat ditingkatkan dengan cara memperluas leksikon dengan mempertimbangkan dialek dan spesifik tema pembicaraan, menambahkan rincian bobot pada sentimen positif dan negatif, meningkatkan kombinasi atau agregasi dari polaritas setiap kata untuk menghitung polaritas keseluruhan teks, melakukan eksperimen yang lebih menyeluruh pada corpus yang lebih besar dan beragam, serta penanganan sarkasme pada suatu teks (Abdulla dkk., 2014). Selain itu, metode berbasis leksikon menghasilkan performa yang baik pada lintas topik pembicaraan, dapat dengan mudah ditingkatkan dengan berbagai sumber pengetahuan, dan tidak memerlukan pelatihan lebih lanjut (Taboada dkk., 2011; Palanisamy, Yadav, dan Elchuri, 2013).

Analisis sentimen berbasis leksikon pada bahasa Indonesia telah dilakukan oleh Pamungkas dan Putri (2016) dengan melakukan analisis sentimen komentar pengguna pada Google PlayStore dan Apple AppStore. Penelitian tersebut menggunakan sentimen leksikon
Inggris (SentiWordNet) sehingga perlu dilakukan penerjemahan teks ke dalam bahasa Inggris terlebih dahulu. SentiWordNet memiliki lebih dari 100000 kata berikut makna polisemi dan skor polaritasnya (positif dan negatif) sehingga banyak digunakan di berbagai studi analisis sentimen (Pamungkas dan Putri, 2016; Baccianella, Esuli, dan Sebastiani, 2010). Akurasi yang dihasilkan pada penelitian tersebut sebesar $68 \%$. Kekurangan pada penelitian Pamungkas dan Putri (2016) adalah metode yang digunakan tidak dapat menangani bahasa tidak baku, fenomena thwarted expectation, dan kata yang bersifat polisemi sehingga sulit menentukan makna yang tepat dalam kalimat. Adapun fenomena thwarted expectation terjadi ketika suatu teks menjelaskan ekpektasi yang selanjutnya menjelaskan kekecewaan terhadap suatu hal.

Penelitian berikutnya tentang analisis sentimen berbasis leksikon pada bahasa Indonesia dilakukan oleh Lailiyah, Sumpeno, dan Purnama (2017) dengan melakukan analisis sentimen pada data pengaduan publik di Twitter dan situs pemerintah. Lailiyah, Sumpeno, dan Purnama (2017) membandingkan akurasi pada penggunaan dua lexical resource, yaitu sentimen leksikon Indonesia dan SentiWordNet. Akurasi yang dihasilkan sentimen leksikon Indonesia lebih tinggi dibandingkan dengan SentiWordNet ketika diujikan pada data berbahasa Indonesia. Akurasi yang dihasilkan meningkat dari $47 \%$ menjadi $65.4 \%$ pada data Twitter dan meningkat dari $56.85 \%$ menjadi $81.4 \%$ pada data situs pemerintah. Namun, penelitian Lailiyah, Sumpeno, dan Purnama (2017) masih belum mempertimbangkan pengingkaran dalam suatu kalimat.

Penelitian Saputra dan Nurhadryani (2018) telah meningkatkan akurasi dari penelitian Lailiyah, Sumpeno, dan Purnama (2017) dengan mempertimbangkan pengingkaran dan struktur gramatikal kalimat dalam bahasa Indonesia. Penanganan struktur gramatikal kalimat dapat mengatasi kesalahan klasifikasi pada kalimat majemuk. Akurasi yang dihasilkan meningkat dari $60.15 \%$ menjadi $63.7 \%$ ketika diterapkan pada data twit Pilgub Jabar 2018. Salah satu kekurangan pada penelitian Saputra dan Nurhadryani (2018) adalah sentimen leksikon Indonesia masih belum bisa membedakan kata berdasarkan kelas kata sehingga terjadi ambiguitas. Sebagai contoh, kata "bisa" dalam kata kerja artinya "dapat" yang bermakna positif, sedangkan kata "bisa" dalam kata benda merupakan zat beracun yang bermakna negatif. Namun menurut Li, Zhu, dan Zhang (2011), membedakan makna kata berdasarkan kelas kata tidak meningkatkan akurasi. Oleh karena itu, penelitian ini belum berfokus pada pembuatan sentimen leksikon Indonesia yang dapat membedakan setiap kata berdasarkan kelas kata. Kekurangan lainnya yaitu, sentimen leksikon Indonesia yang digunakan masih relatif sedikit dan perhitungan bobot hanya menghitung frekuensi kemunculan kata berdasarkan sentimen leksikon saja tanpa memperhatikan makna dalam hubungan antarkata. Adapun fitur yang digunakan 
biasanya adalah bag-of-word. Hal tersebut menyebabkan hilangnya informasi pada hubungan setiap kata (Pak dan Paroubek, 2011; Li dkk., 2010). Adapun hubungan antarkata dapat mengubah polaritas sentimen pada teks. Hubungan antarkata dalam suatu teks dapat direpresentasikan dengan baik menggunakan struktur tree (Pak dan Paroubek, 2011). Adapun struktur tree dapat merepresentasikan hirarki dalam pembentukan kalimat.

Penelitian analisis sentimen berbasis tree sebelumnya hanya memanfaatkan struktur tree sebagai ekstraksi fitur yang hasilnya kemudian digunakan pada pelatihan berbasis machine learning dan deep learning. Nakagawa, Inui, dan Kurohashi (2010) menggunakan struktur tree sebagai hidden variable pada metode klasifikasi conditional random fields (CRFs) dengan rata-rata akurasi $84 \%$ pada data berbahasa Jepang dan 81.3\% pada data berbahasa Inggris. Pak dan Parobuek (2011) menggunakan struktur tree untuk menghasilkan feature vector pada metode klasifikasi SVM dengan akurasi $85.1 \%$. Penelitian menggunakan deep learning dilakukan oleh Teng dan Zhang (2017) menggunakan bidirectional tree LSTM dengan akurasi 94.8\%. Ketiga penelitian tersebut menunjukkan bahwa analisis sentimen menggunakan struktur tree dapat menghasilkan akurasi yang cukup baik (lebih dari 80\%). Akan tetapi penelitian tersebut memiliki biaya komputasi yang lebih besar dibanding analisis sentimen berbasis leksikon karena melakukan konstruksi tree sekaligus pelatihan data. Maka dari itu analisis sentimen berbasis leksikon menggunakan struktur tree perlu dilakukan untuk memperkecil biaya komputasi.

Berdasarkan permasalahan pada penelitan sebelumnya, penelitian ini bertujuan untuk meningkatkan performa analisis sentimen berbasis leksikon sebelumnya dengan menangani kata tidak baku dan menggunakan struktur tree sebagai interpretasi hubungan antarkata dalam suatu teks. Struktur tree dibangun dengan mempertimbangkan penambahan kata pada sentimen leksikon. Hasil penelitian ini diharapkan dapat menghasilkan model analisis sentimen berbasis leksikon yang memiliki performa tinggi dan stabil pada berbagai lintas topik tanpa pelatihan.

\section{METODE PENELITIAN}

\subsection{Data Penelitian}

Data yang digunakan pada penelitian ini adalah sebagai berikut:

1. Dataset Sentiment Lexicons for 81 Languages berdasarkan penelitian Chen dan Skiena (2014) sebagai sentimen leksikon Indonesia.

2. Daftar kata baku berdasarkan penelitian Aziz (2013). Daftar kata baku ini digunakan untuk merubah kata tidak baku menjadi kata baku.

3. Daftar kata konjungsi sebagai tanda pemisah antarklausa dari penelitian Alwi dkk. (2010).

4. Daftar tanda baca sebagai tanda pemisah antarklausa. Tanda baca yang digunakan yaitu, tanda titik, koma, titik koma, seru, tanya dan ampersan (Wahyuni, Krishandini, dan Defina, 2018).

5. Daftar kata negasi digunakan untuk menegatifkan atau mengingkarkan predikat yang bersumber dari Alwi dkk. (2010).

6. Data uji yang digunakan sebagai berikut:

a. Data twit pada masa kampanye Pilgub Jawa Barat 2018 berdasarkan penelitian Saputra dan Nurhadryani (2018) sebanyak 394 twit.

b. Data twit yang diambil pada masa kampanye Pilpres 2019 pada tanggal 13 Februari - 16 April 2019 secara real-time.

c. Data twit yang diambil pada masa pandemik COVID-19 pada tanggal 16 April 2020 - 15 Mei 2020 secara real-time.

Tabel 1 menjelaskan kata kunci yang digunakan dalam pencarian data twit. Komposisi kelas sentimen pada data sampel ditunjukkan pada Tabel 2. Tabel 2 menunjukkan bahwa ketiga data sampel memiliki proporsi antar kelas yang tidak seimbang di mana kelas positif memiliki proporsi terbesar.

Tabel 1 Kata kunci pencarian data twit Pilpres 2019 dan Pandemik COVID-19 berdasarkan nama akun dan tagar

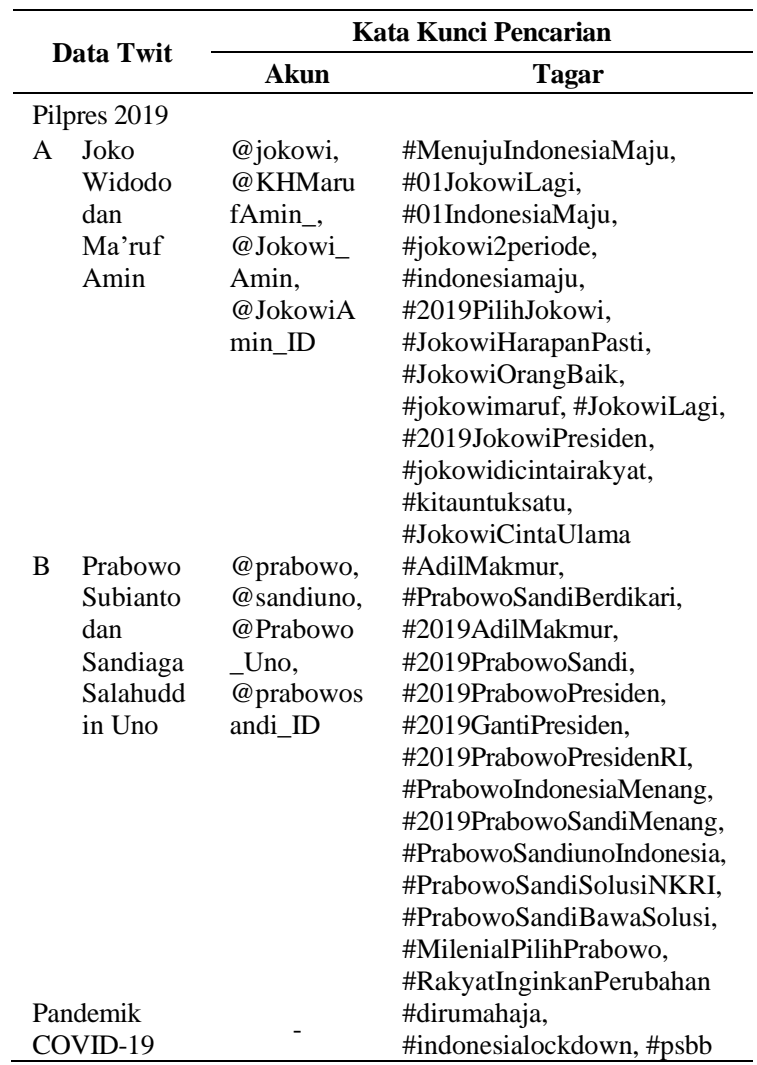

Tabel 2 Distribusi kelas sentimen pada data sampel

\begin{tabular}{lcccc}
\hline \multicolumn{1}{c}{ Data } & Positif & Negatif & Netral & Total \\
\hline Pilgub Jabar & 233 & 62 & 99 & \multirow{2}{*}{394} \\
2018 & $(59,14 \%)$ & $(15,74 \%)$ & $(25,13 \%)$ & \\
Pilpres 2019 & 3974 & 3224 & 1505 & 8703 \\
Pandemik & $(45,66 \%)$ & $(37,04 \%)$ & $(17,29 \%)$ & \\
COVID-19 & 249 & 69 & 76 & \multirow{2}{*}{394} \\
\hline
\end{tabular}




\subsection{Tahapan Penelitian}

Penelitian ini terdiri atas beberapa tahapan (Gambar 1).

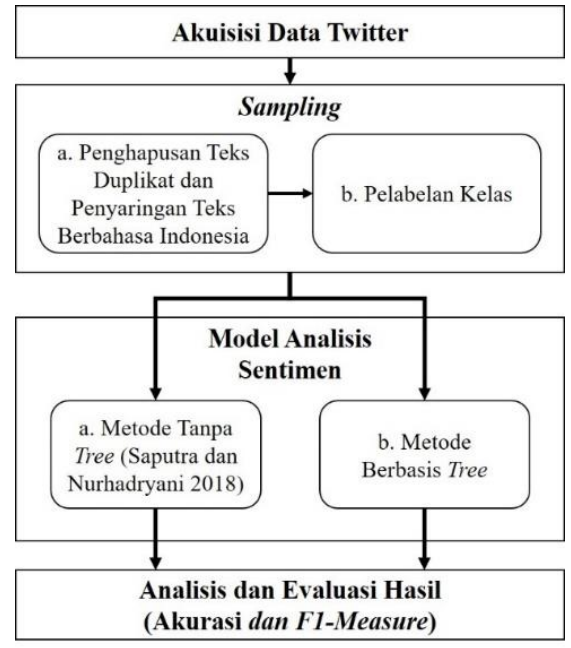

Gambar 1 Tahapan penelitian

Tahapan penelitian ini membentuk tree sebagai interpretasi hubungan antarkata dalam suatu teks untuk membandingkan akurasi dengan penelitian Saputra dan Nurhadryani (2018).

\section{Akuisisi Data Twitter}

Proses akuisisi data yang dilakukan mengacu pada penelitian Saputra dan Nurhadryani (2018). Proses akuisisi data menggunakan library Tweepy. Twit didapatkan dengan API jenis search berdasarkan kata kunci pencarian yang terdiri atas nama akun dan tagar (Tabel 1). Atribut yang diambil adalah atribut "created_at", "user.screen_name", "full text", "user.location". Atribut "full text" yang hanya berisi tautan, tagar (\#), dan mention (@) tidak akan digunakan karena tidak mengandung opini.

\section{Sampling}

Tahap ini merupakan proses pengambilan sampel yang menggambarkan karakteristik dari populasi data twitter yang telah didapatkan pada tahap sebelumnya. Tahap ini terdiri atas praproses data (penghapusan teks duplikat dan penyaringan bahasa Indonesia pada teks) serta pelabelan kelas. Hasil dari tahap ini kemudian digunakan sebagai data uji.

a. Penghapusan Teks Duplikat dan Penyaringan Teks Berbahasa Indonesia

Penghapusan data duplikat dilakukan dengan menggunakan fungsi "Remove Duplicates" pada Microsoft Excel dan pencarian teks bahasa Indonesia menggunakan fungsi "cld2::detect_language()" pada bahasa pemrograman R. Hal tersebut dilakukan untuk mendapatkan data twit yang berbahasa Indonesia saja. Setelah itu, dilakukan penghapusan baris yang mengandung nilai NA pada teks yang bahasanya tidak ditemukan.

b. Pelabelan Kelas
Pelabelan kelas dilakukan secara manual oleh pakar bahasa Indonesia untuk dijadikan sebagai kelas yang diharapkan pada setiap twit yang nantinya digunakan dalam analisis dan evaluasi hasil. Label kelas yang digunakan adalah kelas positif, negatif, dan netral. Melakukan pelabelan data teks diperlukan cukup waktu jika data yang digunakan cukup besar. Untuk mengatasi masalah tersebut dapat dilakukan sampling sebagai representasi keseluruhan data dengan tingkat toleransi tertentu. Persamaan (1) menunjukkan salah satu perhitungan sampling menggunakan rumus Slovin (Umar, 2002). Rumus Slovin digunakan karena cocok digunakan pada data yang besar dan kelasnya tidak diketahui secara pasti.

$n=\frac{N}{1+N e^{2}}$

Di mana :

$n=$ ukuran sampel

$N=$ ukuran populasi

$e=$ margin of error (toleransi ketelitian)

\section{Model Analisis Sentimen}

Data uji yang dihasilkan pada tahap sampling kemudian dimodelkan dengan dua model analisis sentimen yang berbeda. Hal ini dilakukan untuk membandingkan performa yang dihasilkan dari kedua model tersebut. Model analisis sentimen yang dibandingkan pada penelitian ini, yaitu metode tanpa tree dan metode berbasis tree.

a. Metode Tanpa Tree

Tahapan ini menggunakan metode pada penelitian Saputra dan Nurhadryani (2018). Adapun fitur yang diekstrak adalah unigram yang mengandung sentimen positif atau negatif berdasarkan sentimen leksikon Indonesia dengan mempertimbangkan kata negasi, konjungsi, dan tanda baca. Perhitungan bobot pada sentimen leksikon Indonesia diperoleh dari frekuensi kemunculan kata yang sesuai dengan sentimen leksikon Indonesia, jika yang ditemukan kata positif maka skor positif bertambah satu poin, hal tersebut pun berlaku pada kata negatif.

Klasifikasi pada fitur yang diperoleh berdasarkan sentimen leksikon Indonesia hanya membandingkan frekuensi kemunculan kata positif dan kata negatif seperti pada penelitian Lailiyah, Sumpeno, dan Purnama (2017). Jika frekuensi kata positif lebih tinggi maka hasil klasifikasinya adalah kelas positif, hal ini berlaku sebaliknya. Jika frekuensi kata positif sama dengan kata negatif maka hasil klasifikasinya adalah kelas netral.

b. Metode Berbasis Tree

Tahapan ini diusulkan oleh peneliti dengan menggunakan struktur tree sebagai interpretasi hubungan antarkata dalam suatu teks. Metode berbasis tree terdiri atas beberapa tahapan (Gambar 2). 


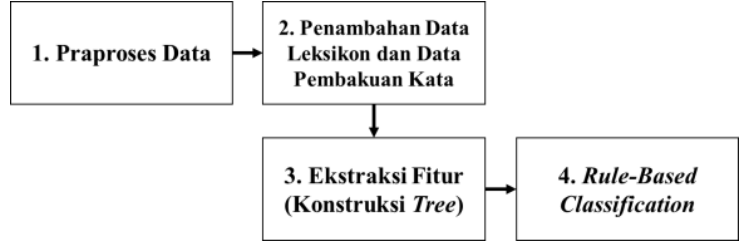

Gambar 2 Tahapan metode berbasis tree

\section{Praproses Data}

Praproses data yang dilakukan terdiri atas pembersihan data, tokenisasi data, mengubah kata menjadi kata baku menggunakan data penelitian Aziz (2013), dan POS Tagging (Gambar 3).

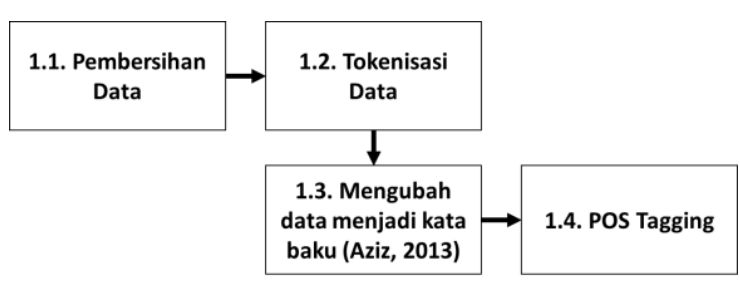

Gambar 3 Tahapan praproses data

Pembersihan data yang dilakukan terdiri atas:

- Penghapusan karakter yang tidak diperlukan seperti simbol, angka, mention, tautan, emoticon, dan karakter "RT" karena hal tersebut tidak mengandung sentimen. Namun, simbol yang terdapat pada daftar tanda baca yang bersumber dari Wahyuni, Krishandini, dan Defina (2018) tidak dihapuskan karena tanda baca tersebut digunakan sebagai pemisah antarklausa. Selain itu, tagar (\#) tidak dihapuskan karena terdapat kemungkinan tagar memiliki sentimen seperti contoh \#Asyik, \#Merdeka, dll.

- Penghapusan kalimat tanya karena kalimat tersebut dianggap netral karena secara eksplisit, suatu pertanyaan tidak memberikan penilaian terhadap suatu hal (dianggap netral).

- Perubahan format teks menjadi huruf kecil.

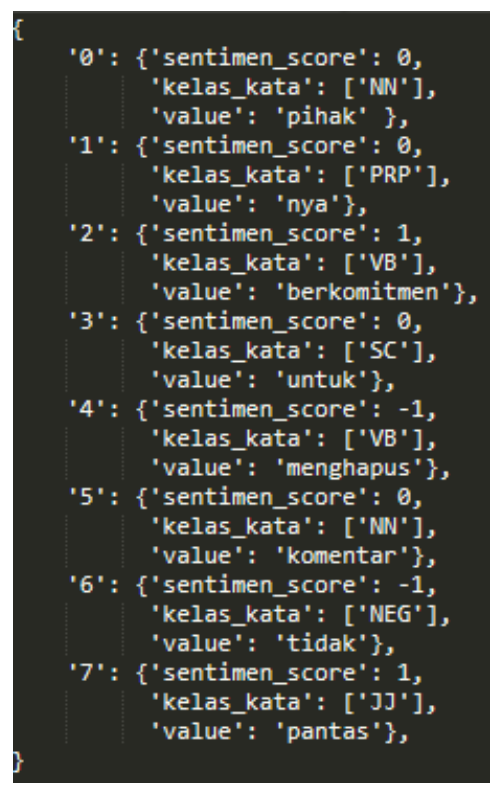

Gambar 4 Hasil praproses data
Tahapan selanjutnya adalah menghasilkan token dalam bentuk dictionary dengan atribut "no_id", "sentimen_score" sebagai positive negative polarity (PN polarity), "value" sebagai kata, dan "kelas_kata" sebagai kelas kata yang setiap katanya sudah diubah menjadi kata baku (Gambar 4). Kelas kata didapatkan menggunakan metode POS tagging pada penelitian Rashel dkk. (2014) yang secara umum dapat ditunjukkan pada Gambar 5. Adapun kata pada token telah diubah menjadi kata baku.

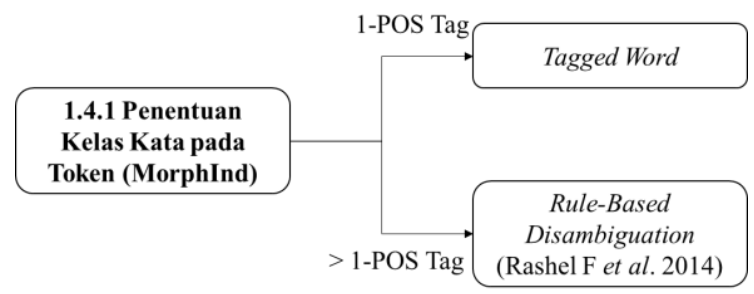

Gambar 5 Tahapan POS Tagging pada penelitian Rashel dkk. (2014)

2. Penambahan Data Leksikon dan Data Pembakuan Kata

Setiap kata yang telah dipecah pada praproses data dilakukan pelabelan manual untuk menentukan polaritas setiap kata yang diverifikasi oleh pakar bahasa Indonesia. Penentuan polaritas ini dijadikan sebagai acuan untuk menambahkan kata-kata pada sentimen leksikon Indonesia. Skema pada penambahan data leksikon dibagi menjadi dua, yaitu hanya menambahkan leksikon dan menambahkan sekaligus memvalidasi leksikon. Validasi yang dilakukan adalah dengan mengubah polaritas kata pada sentimen leksikon ke polaritas yang sebenarnya, sebagai contoh kata pada sentimen leksikon negatif yang dilabeli sebagai kata positif maka dilakukan penghapusan kata tersebut pada sentimen leksikon negatif dan ditambahkan pada sentimen leksikon positif. Jika kata pada sentimen leksikon negatif dilabeli sebagai kata netral maka hanya dilakukan penghapusan kata. Hal ini berlaku juga pada sentimen leksikon positif. Selain itu, setiap kata yang mengandung kata tidak baku dan bahasa gaul dipadankan dengan kata bakunya secara manual. Tabel 3 menunjukkan contoh validasi dan pemadanan kata tidak baku ke kata baku.

Tabel 3 Contoh validasi dan pemadanan kata tidak baku ke kata baku

\begin{tabular}{lcllll}
\hline \multicolumn{1}{c}{ kata } & $\begin{array}{c}\text { Kelas } \\
\text { kata }\end{array}$ & Leksikon & $\begin{array}{c}\text { Validasi } \\
\text { opini }\end{array}$ & $\begin{array}{c}\text { Kata } \\
\text { baku }\end{array}$ & Evaluasi \\
\hline terselesaikan & $\mathrm{X}$ & Negatif & Positif & benar \\
memainkan & VB & Negatif & Netral & benar \\
tergantikan & VB & Positif & Negatif & benar \\
tanda & NN & Positif & Netral & benar \\
manyep & $X$ & Netral & Positif & mantap & benar \\
\hline
\end{tabular}




\section{Ekstraksi Fitur}

Setiap token yang dihasilkan pada tahapan praproses data dijadikan ke dalam bentuk tree. Adapun root node dijadikan sebagai hasil klasifikasi, child node dijadikan sebagai kelas sementara, dan leaf sebagai term yang memiliki nilai positive negative polarity (PN polarity). Nilai polaritas tersebut didapatkan berdasarkan sentimen leksikon Indonesia. Algoritma yang dilakukan adalah sebagai berikut:

a. Jika kalimat yang akan diklasifikasikan adalah kalimat majemuk, maka akan dipisahkan ke dalam beberapa kalimat berdasarkan tanda baca intonasi selesai, seperti “.”, “!”. Jumlah kalimat yang terpisah menunjukkan jumlah tree yang akan dibentuk.

b. Setiap kalimat dipisahkan ke dalam beberapa klausa jika terdapat kata konjungsi maupun tanda baca intonasi jeda seperti “,”, “;” yang menghubungkannya (Gambar 6).

c. Pembentukan struktur tree diawali dengan membuat node root pada setiap klausa untuk dijadikan sebagai subtree.

d. Pembentukan struktur tree dilanjutkan pada setiap subtree dengan mengunjungi setiap term pada token yang telah terpisah oleh konjungsi.

e. Konjungsi yang ditemukan dijadikan sebagai node cabang untuk menggabungkan kembali antarklausa menjadi suatu kalimat.

Tree yang dihasilkan oleh algoritma tersebut dapat dilihat pada Gambar 7.

Pihaknya berkomitmen (untuk, konjungsi) menghapus komentar (tidak, negasi) pantas

(Pemisahan klausa)

1. Pihaknya berkomitmen

2. menghapus komentar (tidak, negasi) pantas

Gambar 6 Pemisahan klausa pada token

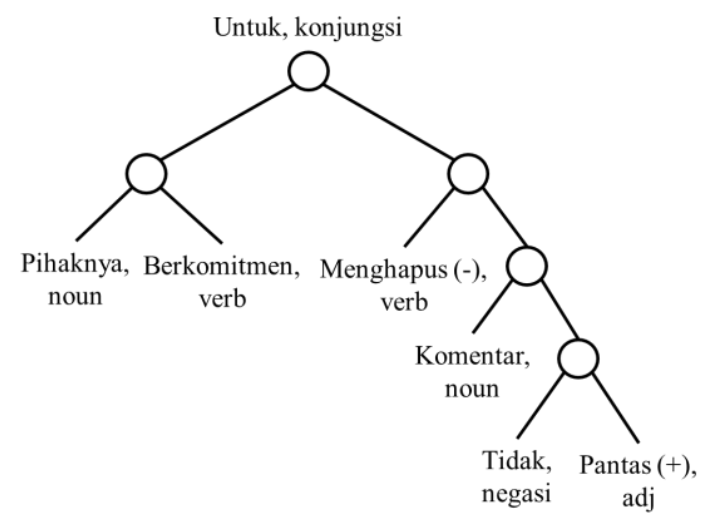

Gambar 7 Tree yang dihasilkan

4. Klasifikasi Menggunakan Rule-Based Classification

Tahapan ini menggunakan aturan-aturan dalam pembentukan struktur tree sebagai interpretasi hubungan antarkata dalam suatu teks. Setiap leaf pada tree yang dihasilkan memiliki nilai positive negative polarity (PN polarity) masing-masing. Nilai-nilai tersebut akan digabungkan untuk menentukan keseluruhan polaritas tersebut (hasil klasifikasi) dalam suatu teks berdasarkan polaritas dari hubungan antarkata. Hasil penggabungan akan disimpan pada parent node dari setiap leaf tersebut sebagai kelas sementara. Penentuan polaritas dari hubungan antarkata dilakukan dengan melakukan penelusuran tree dari level terendah (bottom-up) dengan mempertimbangkan rule tertentu. Rule yang digunakan dalam menentukan polaritas dari hubungan antarkata, yaitu:

a. menggunakan sifat perkalian kedua bilangan positif dan negatif (Tabel 4).

b. menggunakan sifat logika matematika seperti konjungsi untuk kata "dan" (Tabel 5) dan disjungsi untuk kata "atau" (Tabel 6).

c. kata negasi memiliki nilai sentimen negatif karena kata tersebut digunakan sebagai pengingkaran dari suatu pernyataan.

d. menggunakan sifat hubungan kata benda dengan kata sifat dan kata kerja (Tabel 7).

e. menggunakan sifat hubungan kata kerja dengan kata sifat (Tabel 8).

f. penelusuran tree tidak dilakukan pada right node subtree yang memiliki parent konjungsi konsesif.

g. penelusuran tree tidak dilakukan pada left node subtree yang memiliki parent konjungsi "tetapi". Ilustrasi penelusuran tree yang dihasilkan dapat dilihat pada Gambar 8 .

Tabel 4 Rule dalam menentukan polaritas hubungan antarkata menggunakan sifat perkalian dua bilangan

\begin{tabular}{ccc}
\hline Kata 1 & Kata 2 & Kelas \\
\hline+ & + & + \\
+ & - & - \\
- & + & - \\
- & - & + \\
\hline
\end{tabular}

Tabel 5 Rule dalam menentukan polaritas hubungan antarkata

\begin{tabular}{ccc}
\multicolumn{3}{c}{ menggunakan sifat logika matematika konjungsi } \\
\hline Kata 1 & Kata 2 & Kelas \\
\hline+ & + & + \\
+ & - & - \\
- & + & - \\
- & - & - \\
\hline
\end{tabular}

Tabel 6 Rule dalam menentukan polaritas hubungan antarkata menggunakan sifat logika matematika disjungsi

\begin{tabular}{ccc}
\hline Kata 1 & Kata 2 & Kelas \\
\hline+ & + & + \\
+ & - & + \\
- & + & + \\
- & - & - \\
\hline
\end{tabular}


Tabel 7 Rule dalam menentukan polaritas hubungan antarkata menggunakan sifat hubungan kata benda dengan kata sifat dan

\begin{tabular}{ccc}
\multicolumn{3}{c}{ kata kerja } \\
\hline Kata 1 (NN) & Kata 2 (JJ or VB) & Kelas \\
\hline- & + & - \\
- & - & - \\
+ & + & + \\
+ & - & - \\
\hline
\end{tabular}

Tabel 8 Rule dalam menentukan polaritas hubungan antarkata menggunakan sifat hubungan kata kerja dengan kata sifat

\begin{tabular}{ccc}
\hline Kata 1 (VB) & Kata 2 (JJ) & Kelas \\
\hline- & + & - \\
- & - & - \\
+ & + & + \\
+ & - & - \\
\hline
\end{tabular}

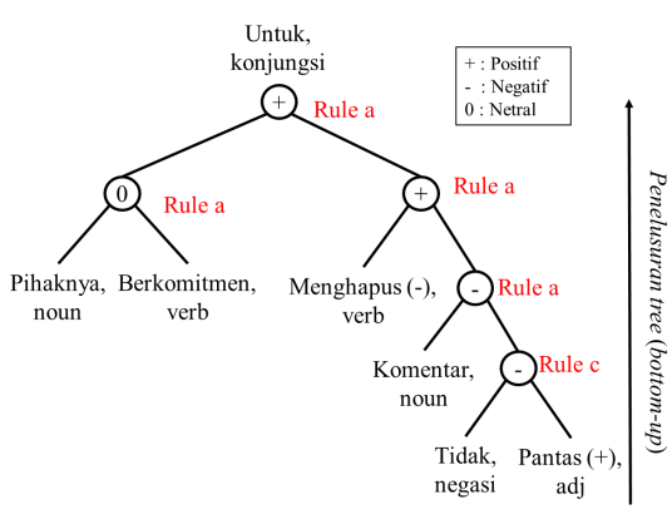

Gambar 8 Penelusuran tree dalam penentuan kelas (klasifikasi)

\section{Analisis dan Evaluasi Hasil}

Tahapan ini mengukur performa dari kedua pemodelan klasifikasi pada ketiga data uji yang digunakan. Pengukuran ini biasanya menggunakan perhitungan akurasi (Han, Kamber, dan Pei, 2012). Pengukuran performa yang digunakan pada penelitian ini adalah pengukuran akurasi dan $f 1$ measure.

F1-measure digunakan untuk membandingkan tingkat akurasi ke dalam satu nilai berdasarkan nilai precision dan recall. Precision dapat dianggap sebagai ukuran ketepatan yang menunjukkan persentase ketepatan sistem dalam memprediksi data sesuai kelasnya, sedangkan recall adalah ukuran kelengkapan yang menunjukkan seberapa lengkap hasil relevan yang ditampilkan oleh sistem.

Pengukuran precision, recall, akurasi, dan $f 1$ measure berdasarkan Persamaan (2), (3), (4), dan (5). Pengukuran precision, recall, dan fl-measure dilakukan pada setiap kelas sehingga setiap pengukuran memiliki tiga nilai. Keseluruhan skor f1measure dihitung berdasarkan weighted fl-measure yang menjadikan setiap ukuran sampel kelas sebagai bobot. Weighted fl-measure dipilih karena analisis sentimen bersifat multi-class dan jumlah data antar kelas yang digunakan tidak seimbang. Pengukuran akurasi, precision, recall, dan fl-measure dihitung berdasarkan tabel Confusion Matrix. Persamaan (2) menunjukkan perhitungan akurasi. Terdapat empat istilah pada tabel Confusion Matrix, yaitu sebagai berikut:

1. TP (True Positives) adalah data aktual positif diprediksi benar oleh klasifikasi.

2. FP (False Positives) adalah data aktual negatif diprediksi salah oleh klasfikasi.

3. FN (False Negatives) adalah data aktual positif diprediksi salah oleh klasifikasi.

4. TN (True Negatives) adalah data aktual negatif diprediksi benar oleh klasifikasi.

Precision $=\frac{\mathrm{TP}}{T P+F P}$

Recall $=\frac{T P}{T P+F N}$

Akurasi $=\frac{T P+T N}{\mathrm{TP}+\mathrm{TN}+\mathrm{FP}+\mathrm{FN}}$

F1-Measure $=\frac{2 *(\text { Precision } * \text { Recall })}{\text { Precision }+ \text { Recall }}$

\section{HASIL DAN PEMBAHASAN}

\subsection{Akuisisi Data Twitter}

Data twit tentang Pilpres 2019 telah terkumpul 187450 data. Data twit tentang pandemik COVID-19 telah terkumpul 16374 data twit.

\subsection{Sampling}

Jumlah kedua data hasil sampling dapat dilihat pada Tabel 9. Jumlah sampel pada data Pilpres 2019 menggunakan metode Slovin dengan tingkat toleransi sebesar 1\%, sedangkan pada data pandemik COVID19 hanya menggunakan random sampling saja dengan jumlah yang sama dengan data Pilgub Jabar 2018 karena data ini dijadikan sebagai data uji tambahan.

\begin{tabular}{|c|c|c|c|}
\hline \multirow{2}{*}{$\begin{array}{l}\text { Tahap } \\
\text { Sampling }\end{array}$} & \multicolumn{3}{|c|}{ Data Twit } \\
\hline & $\begin{array}{c}\text { Pilgub } \\
\text { Jabar 2018 }\end{array}$ & $\begin{array}{c}\text { Pilpres } \\
2019\end{array}$ & $\begin{array}{l}\text { Pandemik } \\
\text { COVID-19 }\end{array}$ \\
\hline Data Awal & - & 187450 & 16374 \\
\hline $\begin{array}{l}\text { Setelah } \\
\text { Penghapusan } \\
\text { Teks Duplikat } \\
\text { Data Teks }\end{array}$ & - & 120713 & 11707 \\
\hline $\begin{array}{l}\text { Berbahasa } \\
\text { Indonesia }\end{array}$ & - & 106753 & 10026 \\
\hline Data Tanpa NA & - & 67089 & 7793 \\
\hline Jumlah Sampel & 394 & 8703 & 394 \\
\hline
\end{tabular}

\subsection{Model Analisis Sentimen}

Model analisis sentimen diimplementasikan menggunakan Python 3. Pada metode berbasis tree dilakukan penambahan data leksikon dan pembakuan kata, sedangkan pada metode tanpa tree tidak.

Data sampel yang digunakan untuk penambahan data leksikon dan pembakuan kata adalah data twit 
tentang Pilpres 2019 yang berjumlah 8703. Jumlah kata yang dihasilkan dari data sampel tersebut 15435 . Tabel 10 menjelaskan jumlah penambahan kata tiap kelas sentimen pada sentimen leksikon berdasarkan data sampel.

Tabel 10 Jumlah penambahan kata pada sentimen leksikon

\begin{tabular}{lccc} 
Keterangan & $\begin{array}{c}\text { Jumlah } \\
\text { Kata } \\
\text { Awal }\end{array}$ & $\begin{array}{c}\text { Jumlah } \\
\text { Penambahan } \\
\text { Kata }\end{array}$ & Total \\
\hline Kata positif & 1075 & 1801 & 2876 \\
Kata negatif & 1825 & 1485 & 3310
\end{tabular}

Tabel 11 menjelaskan jumlah penambahan kata tiap kelas sentimen yang sekaligus divalidasi pada sentimen leksikon berdasarkan data sampel. Jumlah kata tidak baku yang ditemukan pada data sampel berjumlah 1478 sehingga total jumlah data pembakuan kata sebesar 5198. Ilustrasi hasil implementasi pada model tanpa tree dan berbasis tree dapat dilihat pada Tabel 12.

Tabel 11 Jumlah penambahan kata yang sekaligus divalidasi pada sentimen leksikon berdasarkan data sampel

\begin{tabular}{lcc}
\multicolumn{1}{c}{ Keterangan } & $\begin{array}{c}\text { Jumlah Kata } \\
\text { positif }\end{array}$ & $\begin{array}{c}\text { Jumlah Kata } \\
\text { negatif }\end{array}$ \\
\hline Kata Awal & 1075 & 1825 \\
Penambahan Kata & 1808 & 1488 \\
$\begin{array}{l}\text { Penghapusan Kata } \\
\text { Karena Netral }\end{array}$ & 86 & 163 \\
$\begin{array}{l}\text { Penghapusan Kata } \\
\text { Karena Positif } \\
\text { Penghapusan Kata } \\
\text { Karena Negatif }\end{array}$ & - & 43 \\
\hline \multicolumn{1}{c}{ Total } & 20 & - \\
\hline & $\mathbf{2 8 7 6}$ & $\mathbf{3 3 1 0}$ \\
\hline
\end{tabular}

Contoh data twit pada Tabel 12 menunjukkan bahwa hasil sentimen metode berbasis tree sesuai dengan sentimen aktualnya, yaitu positif. Pada metode tanpa tree, kata "kebakaran" tidak terdapat pada sentimen leksikon sehingga kata tersebut dianggap netral. Andaikan kata "kebakaran" ada dalam sentimen leksikon dan bernilai negatif pada metode tanpa tree, hasil klasifikasinya tetap salah. Adapun hasil klasifikasinya adalah negatif.

Tabel 12 Hasil implementasi

\begin{tabular}{ll}
\hline \multicolumn{3}{c}{ Tabel 12 Hasil implementasi } \\
\hline Twit & $\begin{array}{l}\text { RT @ PutriYadis: \#TauGakSih pak Jokowi } \\
\text { berhasil menurunkan angka kebakaran hutan } \\
\text { gambut }\end{array}$ \\
& Sentimen Aktual : Positif \\
\hline $\begin{array}{l}\text { Metode } \\
\text { Tanpa } \\
\text { Tree }\end{array}$ & $\begin{array}{l}\text { berhasil (+), menurunkan }(-) . \\
\text { skor positif }=1, \text { skor negatif }=1\end{array}$ \\
& Hasil Sentimen : Netral
\end{tabular}

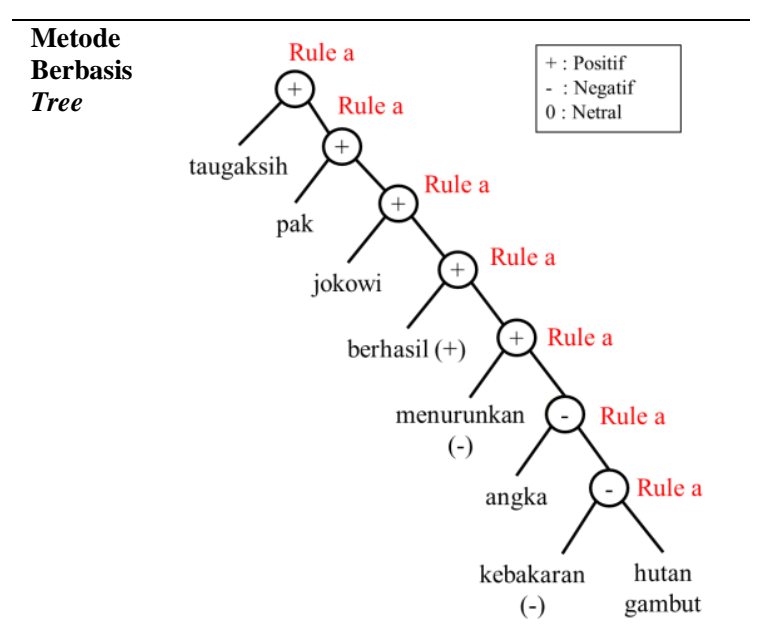

Hasil Sentimen : Positif

\subsection{Analisis dan Evaluasi Hasil}

Pengujian akurasi dilakukan dengan membandingkan kedua metode pada ketiga data. Tabel 13 menjelaskan hasil akurasi dari pengujian yang dilakukan. Tabel 13 menunjukkan bahwa metode berbasis tree terbukti menghasilkan akurasi yang lebih tinggi dibandingkan metode tanpa tree (Saputra dan Nurhadryani, 2018). Selain itu, metode berbasis tree menghasilkan akurasi yang lebih stabil pada seluruh data uji dengan nilai standar deviasi yang lebih kecil $(0,97 \%)$.

Tabel 13 Hasil akurasi dengan membandingkan kedua metode pada ketiga data

\begin{tabular}{lcccc}
\hline \multirow{3}{*}{ Metode } & \multicolumn{3}{c}{ Data Twit } & \\
\cline { 2 - 4 } & $\begin{array}{c}\text { Pilgub } \\
\text { Jabar } \\
\mathbf{2 0 1 8}\end{array}$ & $\begin{array}{c}\text { Pilpres } \\
\mathbf{2 0 1 9}\end{array}$ & $\begin{array}{c}\text { Pandemik } \\
\text { COVID-19 }\end{array}$ & $\begin{array}{c}\text { Standar } \\
\text { Deviasi }\end{array}$ \\
\hline $\begin{array}{l}\text { Tanpa } \\
\text { Tree }\end{array}$ & $63,71 \%$ & $52,92 \%$ & $58,63 \%$ & $5,4 \%$ \\
$\begin{array}{l}\text { Berbasis } \\
\text { Tree }\end{array}$ & $\mathbf{6 4 , 9 7 \%}$ & $\mathbf{6 4 , 3 3 \%}$ & $\mathbf{6 6 , 2 4 \%}$ & $0,97 \%$ \\
\hline
\end{tabular}

Pengujian weighted fl-measure kemudian dilakukan pada kedua metode (Gambar 9) mengingat ketiga data uji memiliki komposisi kelas yang tidak seimbang. Gambar 9 menunjukkan bahwa metode berbasis tree dapat meningkatkan weighted flmeasure pada data twit Pilpres 2019 sebesar 13.76\% dan pandemik COVID-19 sebesar 4.79\%. Namun pada data twit Pilgub Jabar 2018 nilai weighted flmeasure kedua metode tidak berbeda secara signifikan. Perbandingan hasil uji akurasi dan weighted fl-measure dilakukan untuk mengukur validitas nilai akurasi (Tabel 14). Apabila nilai akurasi dan weighted f1-measure tidak berbeda secara signifikan maka nilai akurasi dianggap valid dan tidak bias terhadap data tidak seimbang. 


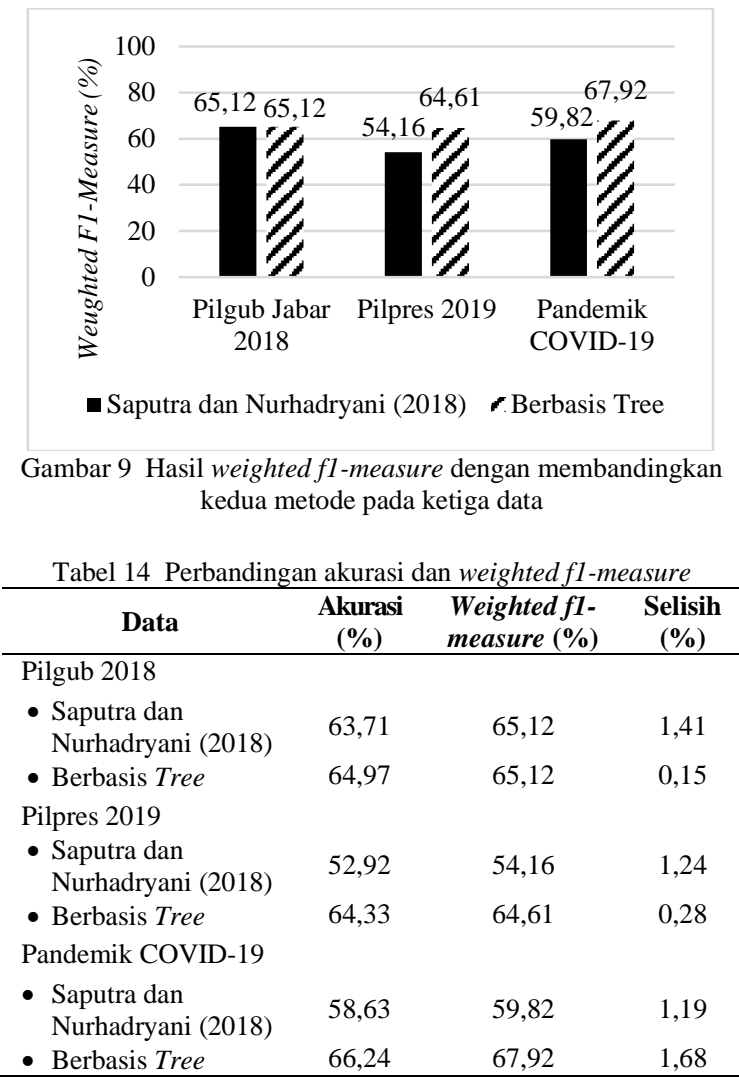

Tabel 14 menunjukkan bahwa kedua metode memiliki selisih yang relatif kecil (kurang dari 2\%) sehingga dapat dikatakan kedua nilai tersebut tidak berbeda secara signifikan. Maka dari itu dapat dikatakan bahwa akurasi kedua metode valid dan tidak bias walaupun jumlah sampel pada setiap kelas tidak seimbang.

Seluruh pengujian yang dilakukan menunjukkan bahwa metode berbasis tree dapat menghasilkan performa yang lebih tinggi dan stabil pada lintas topik. Hal ini menunjukkan hubungan antarkata yang direpresentasikan menggunakan struktur tree berpengaruh terhadap peningkatan performa analisis sentimen berbasis leksikon.

\section{KESIMPULAN}

Penelitian ini menunjukkan bahwa metode berbasis tree terbukti dapat mengatasi kelemahan pada penelitian Saputra dan Nurhadryani (2018). Metode berbasis tree dapat menghasilkan akurasi yang lebih tinggi dari metode tanpa tree (Saputra dan Nurhadryani, 2018) pada seluruh data uji. Peningkatan akurasi pada data Pilgub Jabar 2018 sebesar 1,26\%, data Pilpres 2019 sebesar 11,41\%, dan data Pandemik COVID-19 sebesar 7,61\%.

Selain itu, metode berbasis tree terbukti dapat menghasilkan akurasi yang stabil pada beberapa lintas topik seperti pada data tentang pemilu dan kesehatan. Hal ini tercemin dari standar deviasi akurasi antar data uji yang kecil, yaitu sebesar 0,97\%. Sedangkan metode tanpa tree (Saputra dan
Nurhadryani, 2018) memiliki standar deviasi akurasi yang lebih besar, yaitu sebesar 5,4\%.

Pengujian weighted fl-measure menunjukkan bahwa pada data Pilgub 2018 kedua metode tidak berbeda signifikan. Akan tetapi pada data Pilpres 2019 metode berbasis tree berhasil meningkatkan weighted fl-measure sebesar $10,45 \%$ dan pada data pandemik COVID-19 sebesar 8,1\%. Hasil akurasi dan weighted fl-measure memiliki selisih yang kecil pada kedua metode sehingga pengukuran akurasi kedua metode valid dan tidak bias terhadap data tidak seimbang.

Pengembangan penelitian analisis sentimen selanjutnya dapat dilakukan dengan membuat sentimen leksikon yang dapat membedakan setiap kata berdasarkan kelas katanya sehingga tidak terjadi ambiguitas. Selain itu, algoritme dalam pembentukan tree tidak bisa disamakan karena setiap konjungsi memiliki karakteristik masing-masing dalam pembagian klausa. Oleh karena itu, perlu kajian lebih lanjut pada seluruh konjungsi dalam bahasa Indonesia agar pembagian klausa dalam kalimat sesuai dengan kaidah bahasa Indonesia. Sebagai contoh, pada penelitian ini masih salah dalam melakukan pembagian klausa dengan konjungsi seperti “yang”. Adapun konjungsi tersebut belum melekat pada kata benda. Selain itu, tree yang dihasilkan belum efisien karena seluruh kata pada kalimat dibentuk dalam bentuk tree. Padahal belum tentu semua kata memiliki informasi yang berguna, seperti halnya pada kata keterangan. Kata keterangan hanya memberikan keterangan atau penjelasan lebih lanjut saja terhadap kata dan tidak mengubah sentimen kata. Oleh karena itu, perlu ada pemangkasan tree agar biaya komputasinya lebih kecil.

\section{UCAPAN TERIMA KASIH}

Penulis mengucapkan terima kasih kepada Kementerian Riset dan Teknologi / Badan Riset dan Inovasi Nasional Republik Indonesia yang telah memberikan bantuan melalui program hibah Penelitian Tesis Magister (PTM) dengan nomor 4281/IT3.L1/PN/2020 tanggal 12 Mei 2020 sehingga naskah jurnal ini dapat diterbitkan. Semoga hasil penelitian ini dapat bermanfaat bagi peneliti lain maupun masyarakat luas.

\section{DAFTAR PUSTAKA}

ABDULLA N.A., AHMED N.A., SHEHAB M.A., dan AL-AYYOUB M., 2013. Arabic sentiment analysis: Lexicon-based and corpus-based. Dalam: IEEE Jordan conference on applied electrical engineering and computing technologies (AEECT). Jordan (JO): IEEE, pp.1-6.

ABDULLA N.A., AHMED N.A., SHEHAB M.A., AL-AYYOUB M., AL-KABI M.N., dan AL-RIFAI S., 2014. Towards improving the lexicon-based approach for arabic sentiment analysis. International Journal of 
144 Jurnal Teknologi Informasi dan Ilmu Komputer (JTIIK), Vol. 8, No. 1, Februari 2021, hlm. 135-146

Information Technology and Web Engineering, 9(3), pp.55-71.

ALWI H., DARDJOWIDJOJO S., LAPOLIWA H., dan MOELIONO A.M., 2010. Tata Bahasa Baku Bahasa Indonesia: Edisi Ketiga. Jakarta: Pusat Bahasa dan Balai Pustaka.

APJII (Asosiasi Penyelenggara Jasa Internet Indonesia), 2018. Penetrasi dan Perilaku Pengguna Internet Indonesia 2018, [online] Tersedia di: <https://apjii.or.id/survei2018/ download/cdKN5zPDGmQWkwvVIByZM 1SlsXjaCA> [Diakses 23 Agustus 2020].

AZIZ A.T.A., 2013. Sistem Pengklasifikasian Entitas pada Pesan Twitter Menggunakan Ekspresi Regular dan Nä̈ve Bayes. [skripsi] Institut Pertanian Bogor, Indonesia.

BACCIANELLA S., ESULI A., dan SEBASTIANI F., 2010. Sentiwordnet 3.0: an enhanced lexical resource for sentiment analysis and opinion mining. Dalam: Language Resources and Evaluation (LREC), vol. 10, no. 2010, pp. 2200-2204.

CHEN Y., dan SKIENA S., 2014. Building Sentiment Lexicons for All Major Languages. Dalam: Proceedings of the 52nd Annual Meeting of the Association for Computational Linguistics. Baltimore (US): ACL, pp.383389.

HAN J., KAMBER M., dan PEI J., 2012. Data Mining Concept and Techniques. Ed ke-3. Waltham: Elsevier Inc.

INDURKHYA N., dan DAMERAU F.J., 2010. Handbook of Natural Languange Processing Second Edition. Boca Raton: Taylor and Francis Group.

KWAK H., LEE C., PARK H., dan MOON S., 2010. What is Twitter, a Social Network or a News Media?. Dalam: Proceedings of the 19th International Conference on World Wide Web (WWW'10). Raleigh (US): ACM, pp.591-600.

LAILIYAH M., SUMPENO S., dan PURNAMA I.E., 2017. Sentiment analysis of public complaints using lexical resources between Indonesian sentiment lexicon and Sentiwordnet. Dalam: International Seminar on Intelligent Technology and Its Applications (ISITIA). Surabaya (ID). IEEE, pp. 307-312.

LI B., ZHOU L., FENG S., dan WONG K.F., 2010. A Unified Graph Model for Sentence-Based Opinion Retrieval. Dalam: Proceedings of the 48th Annual Meeting of the Association for Computational Linguistics (ACL). Uppsala (SE): ACL, hlm. 1367-1375.

LI P., ZHU Q., dan ZHANG W., 2011. A dependency tree based approach for sentence-level sentiment classification. Dalam: 12th
International Conference on Software Engineering, Artificial Intelligence, Networking and Parallel/Distributed Computing (ACIS). Sydney (AU): IEEE, pp. 166-171.

NAKAGAWA T., INUI K., dan KUROHASHI S., 2010. Dependency tree-based sentiment classification using CRFs with hidden variables. Dalam: Human Language Technologies: The 2010 Annual Conference of the North American Chapter of the Association for Computational Linguistics (ACL). Los Angeles (US): ACL, pp. 786794.

PAK A., dan PAROUBEK P., 2011. Text representation using dependency tree subgraphs for sentiment analysis. Dalam: International Conference on Database Systems for Advanced Applications. Berlin (DE): Springer, pp.323-332.

PALANISAMY P., YADAV V., dan ELCHURI H., 2013. Serendio: Simple and Practical lexicon based approach to Sentiment Analysis. Dalam: Proceedings of the Seventh International Workshop on Semantic Evaluation (SemEval). Georgia (GE): ACL, pp.543-548.

PAMUNGKAS E.W., dan PUTRI D.G.P, 2016. An experimental study of lexicon-based sentiment analysis on Bahasa Indonesia. Dalam: 6th International Annual Engineering Seminar (InAES). Yogyakarta (ID): IEEE, pp. 28-31.

RASHEL F., LUTHFI A., DINAKARAMANI A., dan MANURUNG R., 2014. Building an Indonesian rule-based part-of-speech tagger. Dalam: 2014 International Conference on Asian Language Processing (IALP). Kuching (MY): IEEE, pp.70-73.

SAPUTRA F.T., dan NURHADRYANI Y., 2018. Analysis of Indonesian Sentiments Using Indonesian Sentiment Lexicon by Considering Denial. Dalam: 2018 International Conference on Advanced Computer Science and Information Systems (ICACSIS). Yogyakarta (ID): IEEE, pp.361366.

SIMON K., 2020. We are Social: Digital 2020 Indonesia, [online] Tersedia di: $<$ https://datareportal.com/reports/digital2020-indonesia> [Diakses 3 Oktober 2020].

TABOADA M., BROOKE J., TOFILOSKI M., VOLL K., dan STEDE M., 2011. Lexiconbased methods for sentiment analysis. Computational linguistics, 37(2), pp.267307.

TENG Z., dan ZHANG Y., 2017. Head-lexicalized bidirectional tree 1stms. Transactions of the 
Association for Computational Linguistics, 5, pp. 163-177.

UMAR H., 2002. Metode Riset Bisnis Panduan Mahasiswa untuk Melaksanakan Riset Dilengkapi Contoh Proposal dan Hasil Riset Bidang Manajemen dan Akuntansi. Jakarta: Gramedia Pustaka Utama.

WAHYUNI E.S., KRISHANDINI, dan DEFINA, 2018. Zona Bahasa. Bogor: Idemedia Pustaka Utama. 
Halaman ini sengaja dikosongkan 